\title{
The use of the job enrichment technique for decision- making in higher education: The case of the Philippines
}

\begin{tabular}{|c|c|}
\hline $\begin{array}{l}\text { Authors: } \\
\text { Kolawole Sam } \\
\text { Chika Sehoole } \\
\text { Constancia G. }\end{array}$ & $\begin{array}{l}\text { uel Adeyemo } \\
1 \\
\text { Cueno }^{2}\end{array}$ \\
\hline \multicolumn{2}{|c|}{$\begin{array}{l}\text { Affiliations: } \\
{ }^{1} \text { Department of Education } \\
\text { Management and Policy } \\
\text { Studies, University of } \\
\text { Pretoria, Groenkloof Campus, } \\
\text { South Africa }\end{array}$} \\
\hline \multicolumn{2}{|c|}{$\begin{array}{l}\text { Q Quality Assurance Unit, } \\
\text { Cavite State University, } \\
\text { Philippines }\end{array}$} \\
\hline \multicolumn{2}{|c|}{$\begin{array}{l}\text { Correspondence to: } \\
\text { Kolawole Samuel Adeyemo }\end{array}$} \\
\hline \multicolumn{2}{|c|}{$\begin{array}{l}\text { Email: } \\
\text { samuel.adeyemo@up.ac.za }\end{array}$} \\
\hline \multicolumn{2}{|c|}{$\begin{array}{l}\text { Postal address: } \\
\text { PO Box 5621, Pretoria 0001, } \\
\text { South Africa }\end{array}$} \\
\hline \multicolumn{2}{|c|}{$\begin{array}{l}\text { Dates: } \\
\text { Received: } 08 \text { May } 2014 \\
\text { Accepted: } 13 \text { July } 2015 \\
\text { Published: } 28 \text { Sept. } 2015\end{array}$} \\
\hline \multicolumn{2}{|c|}{$\begin{array}{l}\text { How to cite this article: } \\
\text { Adeyemo, K.S., Sehoole, C., } \\
\text { \& Cueno, C.G. (2015). } \\
\text { The use of the job } \\
\text { enrichment technique } \\
\text { for decision-making in } \\
\text { higher education: The } \\
\text { case of the Philippines. SA } \\
\text { Journal of Human Resource } \\
\text { Management/SA Tydskrif vir } \\
\text { Menslikehulpbronbestuur, } \\
\text { 13(1), Art. \#645, } 9 \text { pages. } \\
\text { http://dx.doi.org/10.4102/ } \\
\text { sajhrm.v13i1.645 }\end{array}$} \\
\hline \multicolumn{2}{|c|}{$\begin{array}{l}\text { Copyright: } \\
\text { (C) 2015. The Authors. } \\
\text { Licensee: AOSIS } \\
\text { OpenJournals. This work is } \\
\text { licensed under the Creative } \\
\text { Commons Attribution } \\
\text { License. }\end{array}$} \\
\hline \multicolumn{2}{|l|}{ Read online: } \\
\hline 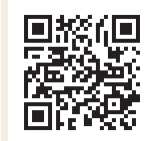 & $\begin{array}{l}\text { Scan this QR } \\
\text { code with your } \\
\text { smart phone or } \\
\text { mobile device } \\
\text { to read online. }\end{array}$ \\
\hline
\end{tabular}

Orientation: This article provides an explorative analysis of the use of the job enrichment technique for decision-making in higher education in the Philippines.

Research purpose: The profile of administrators in charge of decision-making was investigated in terms of their level of familiarity with, and use of, this technique in achieving the goals of enriching jobs, retaining staff and ensuring job-motivation in higher education.

Motivation for the study: Given the increasingly competitive higher education environment in which higher education employees, including academics, work, the pressure on their performance, and their search for ideal working conditions, it is important to measure the impact of the job enrichment technique on employee and higher education organisations.

Research design, approach and method: The study used a quantitative method. The respondents of this study consisted of 206 administrators. Spearman Rank, Correlation Coefficient, Point Bi serial and Chi-square were used to analyse the relationships between the demographic characteristics and job enrichment technique. Multiple Regression Coefficient was used to predict job enrichment.

Main findings: The findings suggest that educational attainment and experience are the most important factors for predicting success as an administrator in higher education.

Practical and managerial implications: Job enrichment should not only focus on the knowledge, experience and skills of administrators, but should be extended to encompass the context and working conditions of employees.

Contribution: In the context of fiscal austerity measures that result in fewer resources becoming available for higher education, it is important to have competent decision-makers who are able to motivate staff.

\section{Introduction}

\section{Global challenges facing the academic profession and motivation in higher education}

Higher education has been faced with complex decisions caused by the increasing challenge of the availability of public resources for higher education. Government must strive to meet competing demands that are made on the fiscal sector, and this has led to several changes and reforms in higher education, worldwide. These changes have occurred in different areas that directly and adversely affect the academic profession:

- terms and conditions of employment have deteriorated and relative salaries have slumped

- members of the academic staff are older

- younger staff members are disproportionately non-tenured and, typically, in part-time employment (Bundy, 2006, p. 8).

These factors compound problems of enrolment, cost containment, budget limitations, restructuring and public pressure for accountability. Resource constraints have led to higher education institutions offering their staff members low salaries and providing poor working conditions which, simultaneously, affect both the performance of the staff and higher education.

The literature shows that higher education has attempted to cope with the challenges of improving job satisfaction by joining industry in adopting classical or modern management approaches, such as the job enrichment technique, amongst others, to improve administrative and organisational efficiency (Valero, 1997). Job enrichment is a motivation technique and it is considered useful in boosting morale of employees and for decision-making. The need to boost employee morale as an important part of management and administration is reflected in a study on Australian higher education (Bexley, James \& Arkoudis, 2011), which found that in 20 universities academics 
were dissatisfied with the lack of recognition of teaching in promotion processes, despite efforts by some universities to include teaching performance and achievement in promotion criteria.

In Australia close to half of the mid- to late-career staff members indicated that their work was a source of considerable personal stress. There were observable mobility plans amongst Australian academics with statistics showing the following trends:

- $25 \%$ intended moving to an overseas institution

- $26 \%$ intended leaving higher education altogether

- another $21 \%$ intended retiring.

Their most common reason was dissatisfaction with institutional or sectorial culture (Bexley et al., 2011). In the US context Rhoades (1998) argues that academics are managed professionals who are increasingly subject to management decisions and are more and more stratified. Altbach, Reisberg and Pacheco (2012) suggest that it has become progressively more difficult to recruit 'the brightest and the best' to academic careers. This, in part, is resultant from the fact that neither salaries nor conditions of service are as attractive as they once were.

Similarly, the Philippines and a number of its higher education institutions have faced deep-seated organisational problems. As a result, there were 35.526 displaced workers in different occupational categories - notably in the education sector (Department of Labour and Employment, 20112013). Reccession, because of the replacement of workers, continued to outpace accession, resulting from the expansion of business activities, including those in the education sector $(11.30 \%$ vs $1.46 \%)$. There were more resignations than layoffs in twelve sub-sectors, including education, and employeeinitiated separations or resignations (3.35\%) exceeded employer-initiated separations or layoffs (2.94\%) (DOLE, 2011-2013, p. 2). A lack of self-motivation or self-satisfaction has contributed to high rates of separation or resignation. The implication of these factors in higher education is that academic staff members who are not happy with their working conditions are more likely to be absent from work and are more likely to quit when better opportunities become available. This has a negative impact on students as less motivated staff members are unlikely to motivate students to excel in their work, and a high staff turn-over from resignations is likely to impact negatively on the students. Moreover, continuity in their learning experience may be disrupted because of exposure to different teaching personnel and styles. The challenges which Philippine higher education faces have a global resonance. In order to guard against the negative effects of this challenge, the job enrichment technique is a strategy that this article advocates. The main objective of this study is to investigate and analyse the demographic characteristics of selected administrators at higher education institutions in the Philippines in terms of the use of the job enrichment technique for decision-making (Figure 1).

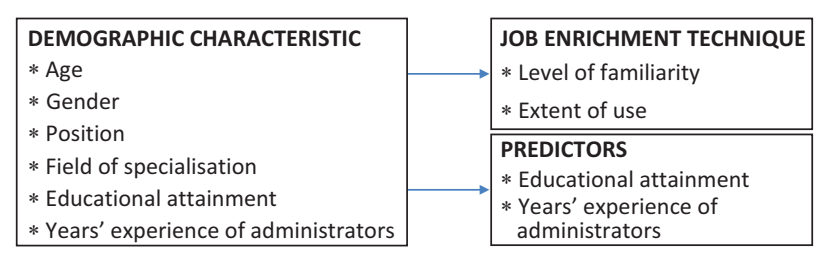

FIGURE 1: The relationship between variables.

This study will contribute new ideas on the use of the job enrichment technique in relation to performance in higher education and, particularly, to its administrators in the decision-making process. Effective use of job enrichment techniques is considered essential to motivate employees to a higher level of productivity, and is useful for administrators to improve performance and quality of higher education.

\section{The Job Characteristic Model}

Several factors can influence heightened job satisfaction and the improved performance of staff members (Orpen, 2011). The Job Characteristic Model developed by Hackman and Oldham (see Figure 2) assumes that if five job characteristics are present, such as skills variety, task variety, task significance, autonomy and feedback, then three psychological states, such as experiencing meaningfulness of work, accepting responsibility of work outcomes, and acquiring a knowledge of results critical to motivation, can be produced and these will lead to good performance amongst employees. Together the combined characteristics can produce positive outcomes, such as internal work motivation, job satisfaction, growth satisfaction, low absenteeism and high quality performance (see Kotila, 2001). If these are combined with a good leadership style, all five of the core dimensions of the Job Characteristic Model in a single job should results in job enrichment (Uduji, 2013), which allows both administrators and academics to grow and develop.

Some elements of the Job Characteristics Model are central to the nature of the academic profession, such as autonomy and feedback, accepting responsibility for work and outcomes and academics need to be given space to do their work. As Locke and Teichler (2007) suggest, academics are a highly select group of people who have succeeded - in most countries and over long periods of history - therefore the governance of their institutions must ensure the highest quality and significance of higher education. Without a strong, well-educated and committed professional body, no academic institution or higher education system can be successful (Altbach et al., 2012). For this reason, higher education institutions need to provide ideal conditions for the recruitment and retention of their staff members. Retention strategies can include the use of the job enrichment technique in a strategic way to support and create enabling conditions for academics to carry out their work. 


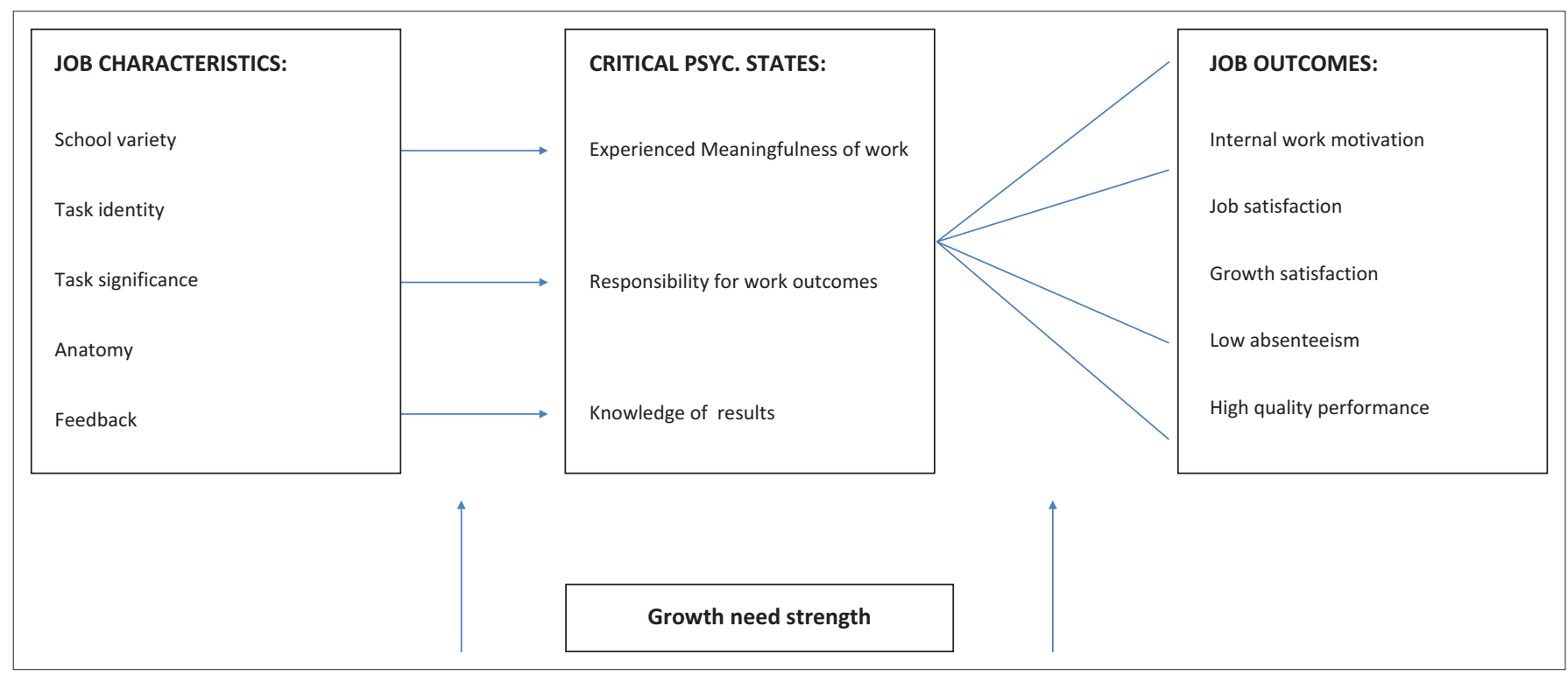

Source: Mione, P. (n.d.). Job enrichment. Retrieved August 22, 2013, from http://edweb.sdsu.edu/people/arossett/pie/Interventions/jobdesign_1.htm and Deom Drez, J. (1999). Motivation through needs, job design, and satisfaction. Chapter 7, slide 20. Retrieved February 14, 2014, from http://www.sui.edu/departments/cola/psyc323/chat07/index.htm

FIGURE 2: Job characteristics model.

In educational organisations the focus should be on motivating staff members to contribute to the aims and objectives of higher education in a particular context. In order to achieve this, employees should not be treated as raw material (input) but they should rather be seen as a constituent part of the process of providing quality education (output). Lunenburg and Ornstein (2008) categorise the operation of higher education into three parts, namely: input, transformation process and output. They explain that output includes:

- employee performance

- the growth levels of employees

- employee turn-over

- employee absenteeism

- employee-management relations

- school community relations

- employee job satisfaction.

In order to avoid the negative effects of a lack of output, administrators in decision-making positions should become familiar with the job enrichment technique, and do so efficiently and effectively to achieve the goals of increasing job performance and the retention staff. A long-standing debate concerns whether or not job satisfaction and a high level of morale improve efficiency and performance in a system, such as higher education. Therefore, it is important to examine the demographic characteristics of administrators who make decisions in higher education, in order to determine their ability to achieve the goals of increasing job performance and the retention of staff rather than to continuously lose them.

\section{Methodology}

The study used multivariate analysis of variance to analyse the use of the job enrichment technique, by staff administrators at universities in the Cavite Province of the Philippines, for decision-making at their institutions.
A survey questionnaire designed by Valero (1997) was adapted to gather the relevant data from 163 administrators using the simple random sampling technique. The items were arranged in different major segments: questions were asked to gather information regarding the demographic characteristics of the respondents, including age, gender, position, experience as an administrator, educational attainment and field of specialisation. Further questions on their familiarity with the job enrichment technique were designed in such a way that they would allow for a matrix of multiple responses from the administrators. Familiarity was categorised into four possible responses:

- Not familiar

- Somehow familiar (no expertise)

- Somewhat familiar (limited expertise)

- Very familiar (expert in its use).

To gather data concerning the extent of the use of the job enrichment technique, an organised matrix table was designed. The columns were labelled in terms of four options:

- never use

- occasionally use (irregularly)

- frequently use (repeatedly)

- always use (extensively).

The data were analysed using the Statistical Package for Social Sciences (SPSS).

To ensure the reliability of the data and to reduce chances of bias, the first part of the questionnaire collected demographic information of the administrators, and the other parts dealt with the level of familiarity and extent of use of the job enrichment technique. The aim was to compare the profile of administrators with the answers they supplied in other part of the questionnaire. Where there were discrepancies in the information that was supplied, follow-up interviews 
were conducted to address and clarify these discrepancies. In addition, document analysis of personnel information/ appraisal was conducted for triangulation purposes. A literature review was conducted to assess the relevance and applicability of the job enrichment technique in the broader higher education environment - other than the Philippines.

\section{The implications of job enrichment in Philippine higher education}

There have been prior studies on the use of the job enrichment technique (Leach \& Wall, 2004; Niehoff, Moorman, Blakely \& Fuller, 2008; Uduji, 2013; Umstot, Bell \& Mitchell, 1976). However, few of these studies examine job enrichment in relation to performance in higher education and, particularly, to its administrators in decision-making (see, for example, Orpen, 2011). Hence, we examine the demographic characteristics of administrators who make decisions in order to determine which of these features will assist them in becoming familiar with, and in using, the job enrichment technique efficiently and effectively.

Making decisions that enhance the job performance of staff at higher education institutions is one of the key roles of higher education administrators. In emphasising this role, the Philippine Education Act of 1985 demands accountability from administrators on decisions taken that are related to the efficient and effective administration and management of their various institutions (Sarmiento III, 2008). The Act mandates all administrators to take full responsibility for their decisions, assuming that they have the expertise and experience to occupy dynamic and decision-making positions (Adeyemo, 2013). This responsibility includes motivating staff to perform in terms of quality teaching and learning. A benefit of improved job enrichment is a higher level of staff retention which contributes to ensuring that quality service is rendered (Riehl, 2000). To achieve the objectives of higher education, job enrichment can be used as a motivating technique whereby employees are given the opportunity to use their abilities (Pillai, Masood, Amoodi, Husain \& Koshy, 2012) and be rewarded accordingly. Hence, job enrichment can be seen as a critical determinant of job involvement and, subsequently, impacts on organisational effectiveness and success (Govender \& Parumasur, 2010).

The effective use of job enrichment can reverse the effects of boredom, lack of flexibility and employee dissatisfaction (Leach \& Wall, 2004). Thus, performance can be enhanced and achieved if employees are motivated and satisfied. However, both employees and organisations need to be assessed and their short-comings addressed before job enrichment can be effective or achieve the expected performance. There is a need to know whether or not employees prefer jobs that involve responsibility, variety, feedback, challenge, accountability, significance and opportunity in order to understand how to motivate them without changing their job classification (Cunningham \& Eberle, 1990). Enriching jobs are particularly effective in developing employees, provided that the jobs are truly enriched and that the process does not just increase the amount of work required of them (Brown, 2004). Similarly, job enrichment should encourage employees to operate more efficiently if they are allowed to take responsibility, learn new skills, and are prepared to advance to a higher position. Consequently, the employees' loyalty can be developed (Niehoff et al., 2008) and they are, thus, likely to stay with an employer for longer. It is evident that job enrichment has a positive effect on job performance (Umstot et al., 1976). If job enrichment can provide such benefits to staff members in educational organisations, then it is important to pay attention to its effective use in the decision-making process.

\section{Age and decision-making}

In terms of age, for instance, Queen and Hess (2010) argue that there is little difference between young and old when it comes to making sensitive decisions. However, age differences are likely to become more significant when it comes to complex decision-making. They further claim that the effects of age in decision-making are not universal. Jennings, Hunt and Munn (1996) believe that most unethical decisions are made by members of the younger age group. In the Philippines the Commission on Higher Education (CHED) issued Memorandum Order No. 6, Series of 2009 which pegged the minimum age of applicants for a position at State Universities and Colleges (SUC). For the position of president, chancellor or vice-chancellor, candidates should not be less than 35 years of age and not more than 61 at the time of their application (CHED, 2009). Adeyemo (2013) reports that many administrators in higher education in the Philippines are in their 50s, whilst a report by the RAND Corporation (1994-2011) asserts that the majority of administrators will not remain in their jobs beyond the age of 55 . For instance, only $14.1 \%$ and $44.8 \%$ of the administrators of this age category were 'somehow' (no expertise) and 'somewhat' (limited expertise) familiar with the job enrichment technique, respectively, whilst $41.1 \%$ of them frequently used it and $9.8 \%$ never used it (Adeyemo, 2013). However, the frequent use of this technique by administrators has not provided a solution for the problem of a high staff turnover rate in the Philippines.

These findings do not reveal that older administrators are able to make more effective decisions or that they are very familiar with, or able to apply, job enrichment in decisionmaking in their various departments or institutions.

\section{Gender and decision-making}

In his study Bell (1995) suggests that male administrators set the standard for what is valued and that female administrators have to prove themselves as effective leaders. Rather than being gender-related Manjider and Priyan (2009) believe that the relevant education that builds knowledge and broadens continuous and comprehensive experience is important for effective decision-making. Essentially, this implies that administrators require relevant training and experience in related fields to perform well in their roles. According to 
the ICFAI University (2005), training should not just focus on stimulating diverse thinking but it should also remove mental blocks, such as the fear of failure, the fear of rejection, and the fear of disapproval. This is even more important in a higher education context where academics cherish their autonomy and are more likely to insist on their rights. Grogan and Andrews (2002) emphasise equal opportunity in assigning positions to employees because poor decisionmaking comes from a lack of knowledge as well as a lack of experience (Jackson \& Kelley, 2002; Knapp, Copland \& Talbert, 2003) and not, necessarily, from gender differences. When applied to academics, poor decision-making can lead to the undermining of, and a lack of respect for, decisionmakers.

\section{Experience as an administrator, level of education and the decision-making position}

Given the complexities and the challenges in higher education for academics, in relation to their working conditions, it is important to examine the experience and level of education of administrators in higher education, with a view to identifying the skills and ideal working conditions which would be relevant for the management of the academics. MacDade (2008) explained that administrators in the United States scarcely anticipated their current administrative positions and they had minimal management training. In surveys of secondary and higher education, administrators have indicated their need for qualifications in related fields of management and sufficient administrative experience before moving into senior leadership positions (MacDade, 2008). Therefore, administrators need both the skills which can be acquired through formal training and experience in order to have complete mastery of all leadership and management roles in an educational organisation.

In the Philippines, the CHED Memorandum No. 16, Series of 2009 stipulates that applicants for the post of president or chancellor at SUC must have at least 5 years of work experience, preferably in an academic field, as president or chancellor, vice-president or vice-chancellor, dean, campus administrator or director. Consequently, decision-making positions cannot be assigned arbitrarily or on the basis of age and gender because productivity and performance are linked to evidence of administrators possessing relevant education, training and experience. In other words, performance is an outcome of trained and experienced administrators. Because of politics - and for many other discriminatory reasons leadership positions are occupied by staff members with little or no experience (Adeyemo, 2013). This practice has not only contributed to low quality education but it is also responsible for the slow growth and development of many higher education institutions.

\section{Demographic characteristics of administrators in this study}

The demographic characteristics of administrators in this study include age, gender, level of education, field of specialisation, position and years of experience as an administrator.

\section{Age}

The age of administrators who participated in the study was categorised in terms of establishing whether they were young, middle-aged, old or older.

\section{Gender}

Gender was categorised as either male or female.

\section{Level of education}

Level of Education was used to determine whether administrators possessed a Bachelor's degree or whether Master's degree studies were being undertaken or completed, or whether doctoral studies were being undertaken or had been completed.

\section{Field of specialisation}

Field of specialisation in this context refers to the administrators' area of specialisation. This was classified into management, medical, science and social sciences.

\section{Position}

Administrators' positions were categorised as:

1. administrative executive that includes president, chancellor, school director and vice-president, deputy vice-chancellor for administration

2. administrative operative that includes administrative directors, administrative heads and coordinators.

Academic executive includes vice-president and vicechancellor for academic affairs; and dean, chairman, and academic coordinator, which were classified as academic operative positions.

\section{Experience as an administrator}

The administrators' years of experience were categorised as reflected in Table 1.

\section{Level of familiarity with the job enrichment technique}

The level of familiarity with the job enrichment technique was classified in terms of whether administrators were 'very familiar', 'somewhat familiar', 'somehow familiar', or 'not familiar' with this technique.

\section{Extent of use of the job enrichment technique}

The extent of use of the job enrichment technique by administrators was classified in terms of whether

TABLE 1: Range qualitative description in terms of administrators' experience.

\begin{tabular}{ll}
\hline Years of experience as administrators & Interpretation \\
\hline Less than 5 years & Minimal administrative experience \\
$5-10$ years & Good administrative experience \\
11 years and above & High administrative experience \\
\hline
\end{tabular}


TABLE 2: Distribution of administrators by population, sample size and actual number of respondents.

\begin{tabular}{lccc}
\hline School administrator & $\begin{array}{c}\text { Population } \\
\text { size }\end{array}$ & $\begin{array}{c}\text { Sample } \\
\text { size }\end{array}$ & $\begin{array}{c}\text { Actual } \\
\text { respondent }\end{array}$ \\
\hline President/Chancellor & 11 & 6 & 5 \\
Vice-President/Vice-Chancellor & 44 & 21 & 8 \\
Dean & 54 & 26 & 18 \\
Director & 21 & 10 & 10 \\
Chairperson & 65 & 31 & 31 \\
Coordinator & 76 & 36 & 31 \\
Registrar/Record & 32 & 15 & 12 \\
Accountant/Bursar & 11 & 6 & 8 \\
Guidance/Student affairs & 22 & 11 & 16 \\
Librarian & 11 & 0 & 6 \\
Others & $\mathbf{7 8}$ & 6 & 18 \\
\hline Total & $\mathbf{4 2 5}$ & $\mathbf{2 0 6}$ & $\mathbf{1 6 3}$ \\
\hline
\end{tabular}

Note: Sampling fraction was used to calculate actual sample size from each category of administrator.

The formula is as follows: $n=N /(1+\mathrm{Ne} 2)$ (Slovin Fomula), Where $N=$ Population size, $n=$ Sample size, $e=$ desire margin of error (which is $5 \%$ ).

$n=425 / 1+425(0.05) 2 ; N=206$ (sample size).

$n=425 / 1+425(0.05) 2, N=206$ (sample size).

The $N$, whertion administrators $/ 425$ administrators $=0.48$ (Sampling fraction) .

administrators 'always', 'frequently', 'occasionally', or 'never' used it in their institutions or departments.

\section{Sampling}

Refer to Table 2 for the sampling.

\section{Results and discussion}

The results and discussion are in terms of the administrators' demographic characteristics and their use of the job enrichment technique.

\section{Administrators' demographic characteristics}

It was found that administrators in the population sample of this study were mostly 50 years and older (31.9\%). Female administrators were in the majority in academic and administrative positions (57.7\%). A Master's degree or $\mathrm{PhD}$ ongoing $(39.3 \%)$ was the highest educational qualification held by the administrators. Many administrators specialised in Social Science fields (32.5\%) and many occupied academic operative positions (47.7\%), such as dean, director, chairman, and coordinator. The majority of administrators (52.8\%) had less than 5 years' experience. The majority of the institutions were privately owned and operated. An analysis of the results shows that administrators in management positions were female and much older than other administrative employees, their education qualifications were below the minimum requirement for the role and were not in a related field of management and they had insufficient work experience in the area of higher education. This poor profile of administrators has implications for decisions that are made which can also affect academics.

The findings confirm the requirements stipulated in the CHED Memorandum Order No. 6, Series of 2009 that the minimum age of applicants for SUC presidency must not be less than 35 years and not more than 61 at the time of the application. It is also in line with the report of the
RAND Corporation (1994-2011) that found that there were relatively few principals (administrators) in their positions beyond the age of 55 . The results imply that administrators in charge of decision-making are relatively older people, but there is no evidence that age helps older administrators make effective decisions to retain staff or that these administrators are very familiar with - or, indeed, always use - the technique.

In terms of the gender, the majority (57.7\%) of administrators in this study are female. The findings are similar to those of Rodeles (2009), who found that the majority of respondents were female, in his study of environmental conditions at a College of Education attached to the De LaSalle UniversityDasmarinas in the Philippines in the school year, 2006-2007. It strengthens the statement by Sarmiento (2008) that gender is not a requirement, but only that an administrator must be a Filipino. The majority of administrators in higher education in the Philippines are female and, if the decisions they are making have not significantly impacted on job-motivation or satisfaction of employees, it is questionable whether or not Filipino female administrators are really able to perform their roles. It should, therefore, be ensured that male and foreign administrators are also well-represented for skills transfer purposes - a way of internationalising the Philippines' higher education.

In terms of educational attainment, the majority of administrators in the sample (39.3\%) had a Master's degree and were studying towards a doctorate, followed by those with a Bachelor's degree (30\%) and a doctorate. Only $25.8 \%$ had completed their doctorate, which is required for a decision-making position in higher education. The study revealed that the majority of administrators in higher education were people who were likely to struggle in making decisions. They would also struggle to integrate people into a work situation that would motivate them to work together productively to achieve the objectives of higher education. The primary duties, of administrators in enriching jobs, are to help employees release and guide their inner drives which they already have in terms of expected performance. This responsibility requires that administrators should have been trained in advanced management and should be experienced in using management-decision tools which require a high-level qualification. This is a fusion process which, simultaneously, serves both personal and organisational objectives (Davis, 1997).

In terms of field of specialisation, the majority of the respondents in the sample for this study specialised mainly in Social Sciences (32.5\%), followed by Management (23.9\%) and then Medicine (17.2\%). The findings contradict Sarmiento's (2008) recommendation that administrators should hold appropriate degrees. An appropriate degree is one in a field of specialisation that is relevant to the administrator's prospective or present position in a department or faculty. It is considered relevant for administrators to hold an academic degree in the field of management, and to use job enrichment to achieve the goals of job-motivation and satisfaction. The 
implications of these results are that administrators are not able to use the job enrichment technique and that the veracity behind the use of decision-making techniques and the management of higher education is not known to them.

In terms of the position, the majority of respondents in the sample for this study hold academic operative positions $(41.7 \%)$, followed by academic executive positions $(13.5 \%)$. The findings clearly show that administrators are paid to make decisions, as the majority are operative academics, such as deans and heads of department. However, there is no evidence to show the importance of these positions or the quality of output of such decisionmaking positions, as the majority of the administrators do not qualify academically for their positions and they have not acquired experience to make job-enriching decisions for their employees.

With regard to the years of experience of administrators, the majority of the respondents in this sample (52.8\%) are newly appointed administrators with less than 5 years of administrative experience in an administrative position followed by those who had up to 10 years of experience $(21.5 \%)$. The findings demonstrate non-compliance with Section 5 of CHED Memorandum No. 16, Series of 2009 which requires an applicant for the post of SUC president, chancellor or vice-chancellor to have at least 5 years of experience - preferably in academic employment as president, vice-president, dean, campus administrator or director. The findings show that the majority of administrators have less than 5 years of experience and this may explain some of the limitations these administrators have in terms of their ability to manage the dynamics of a higher education organisation. In the Philippine context, this situation reflects poor working conditions and salaries which also affect academics and lead to a high staff turnover (DOLE, 2011-2013). One of the signs of deteriorating human relations is the phenomenon known as 'low morale'. High morale is the hallmark of a well-managed higher education institution, but it cannot be forced into existence or bought. Higher education must provide conditions and an environment to make it happen. It is, fundamentally, the result of the good application of the job enrichment technique.

\section{Administrators' demographic characteristics and the use of the job enrichment technique}

The findings, concerning the relationship between administrators' characteristics and their use of enrichment techniques, reveal that only educational attainment $(r=0.303)$ in related fields and experience as an administrator can facilitate the use of the job enrichment technique (Table 3). This, subsequently, will lead tojob-motivation and satisfaction of employees. Other demographic characteristics, such as age, gender, and position were found not to be significantly related to the use of the job enrichment technique. However, administrators should have achieved an appropriate level of education to be able to use the job enrichment technique to create job satisfaction and high performance amongst
TABLE 3: Relationship between administrators' demographic characteristics and the use of job enrichment technique.

\begin{tabular}{lccccl}
\hline $\begin{array}{l}\text { Demographic } \\
\text { characteristic }\end{array}$ & $\begin{array}{c}\text { Chi-square } \\
\text { computed }\end{array}$ & $\begin{array}{c}\text { Degree of } \\
\text { freedom }\end{array}$ & $\boldsymbol{N}$ & $\boldsymbol{P}$-value & Interpretation \\
\hline Age & - & - & $0.174^{*}$ & 0.032 & Not significant \\
$\begin{array}{l}\text { Gender } \\
\begin{array}{l}\text { Educational } \\
\text { attainment }\end{array}\end{array}$ & - & - & $-0.119^{*}$ & 0.066 & Not significant \\
$\begin{array}{l}\text { Field of } \\
\text { specialisation }\end{array}$ & 9.830 & 9 & 0.251 & 0.363 & Not significant \\
$\begin{array}{l}\text { Position } \\
\begin{array}{l}\text { Year of experience } \\
\text { as administrator }\end{array}\end{array}$ & - & 6 & 0.303 & 0.016 & Significant \\
\hline$*$ Chi-square & & - & $0.059 *$ & 0.484 & Not significant \\
\hline
\end{tabular}

* Chi-square.

TABLE 4: Predictors of job enrichment.

\begin{tabular}{lcccc}
\hline Regression parameter & $\begin{array}{c}\text { Regression } \\
\text { coefficient }\end{array}$ & $\begin{array}{c}\text { Standard } \\
\text { error }\end{array}$ & $\boldsymbol{T}$-computed & $\boldsymbol{P}$-value \\
\hline Constant & 3.097 & 0.071 & 43.361 & 0.000 \\
$\begin{array}{l}\text { Educational attainment } \\
\text { with an advanced degree }\end{array}$ & 0.331 & 0.137 & 2.414 & 0.017
\end{tabular}
with an advanced degree

Multiple $r=0.192 ; R$ square $=0.037 ;$ Adjusted $R$ square $=0.030$

$Y=3.097+0.331 \times 1$, Where $Y-$ Level of Familiarity; X1 - Educational Attainment 1 if advanced degree 0 otherwise.

employees and to discourage constant separations or resignations from jobs. This supports the findings of Jackson and Kelley (2002), and Knapp et al. (2003) who maintain that poor decision-making is the result of a lack of knowledge as well as experience. It is, therefore, believed that the limitations of education and experience do affect administrators' levels of familiarity with, and use of, the job enrichment technique at their institutions.

Without relevant experience and qualifications in job enrichment in the Philippines - and in other places administrators will not be able to manage staff members, as they are not likely to be able to utilise management language for boosting moral, nor are they likely to acquire sound information for effective decision-making. Decision-making positions require a sound knowledge of the complex modern human environment in order to enrich employees in their overall performance in the higher education system of any country. There is no magic mirror on which administrators can depend to reflect the attitudes of employees (Cavite State University Module, 2008). They need to actively interact with staff members and learn about their attitudes. In contemporary higher education organisations, major changes have occurred in employee relations policies which have attracted more unqualified academics and have resulted in losing highly qualified academics who have the potential to improve the organisation system of higher education from the inside. More specifically, there is no guarantee that untrained or inexperienced administrators can fill the gap in making decisions concerning job enrichment and satisfaction.

Table 4 reflects the predictors of the job enrichment technique. The results show that the attainment of an advanced degree (0.33) is a determinant in the use of job enrichment for effective decision-making. Therefore, administrators should have an advanced degree or its equivalent to be familiar with, and to be able to use, the job enrichment and motivation technique. 
The findings suggest that only educational attainment and years of experience as an administrator determine or predict familiarity with the role and the use of the job enrichment technique. Although the experience of administrators is important, the level of educational attainment is considered to be more significant in the order of priorities. Nevertheless, the Philippines' higher education has called for internal organisational reform, which is not limited to an improved salary structure and good working conditions, but also to the availability of resources to attract and to retain highly qualified staff in terms of job satisfaction and performance.

\section{Conclusion and recommendations}

This article provides an explorative analysis of the use of the job enrichment technique for decision-making in higher education in the Philippines. It has analysed the impact of this technique on employees and higher education organisations. The profile of administrators in charge of decision-making was investigated in terms of their level of familiarity with, and use of, this technique in achieving the goals of enriching jobs, retaining staff and ensuring job-motivation in higher education. Given the increasingly competitive higher education environment in which higher education employees find themselves, the pressure on their performance, and their search for ideal working conditions, it is important to have competent decision-makers who are able to motivate staff.

It is recommended that administrators should have a relevant qualification and sufficient experience in working in higher education institutions before assuming supervisory roles at educational institutions. These requirements are strongly recommended for administrators, as past experience has an influence on future performance and determines the outcomes and successes of their institutions.

This study further recommends that government regulatory bodies in charge of higher education should examine and place an emphasis and re-emphasise on the administrators' fields of specialisation, their experience as administrators, and their levels of educational attainment. These should be part of the critical requirements to be considered before any learning institution may be issued with a permit to operate as a higher education institution. This should also apply to the appointment of the head of a higher education institution.

Finally, job enrichment should not only focus on the knowledge, experience and skills of administrators, but should be extended to encompass the context and working conditions of employees. Higher education should also be well-resourced to attract a high calibre of qualified and experienced academic and the job enrichment technique should be used to achieve desired results. The appropriate use of resources, combined with well-trained and qualified decision-makers will go far in developing the capacity to reverse the slump in conditions of employment, such as poor salaries, increased workloads and stress levels, and the compounding challenges of motivating academic staff in terms of efficiency. This, in turn, will result in creating ideal conditions to attract the brightest minds to the academic profession, which is important in an increasingly globalised world where academics should be encouraged and their jobs should be enriched in order for them to perform optimally in the workplace.

\section{Acknowledgements Competing interests}

The authors declare that they have no financial or personal relationships which may have inappropriately influenced them in writing this article.

\section{Authors' contributions}

K.S.A. (University of Pretoria) was the lead writer and responsible for the research conceptualisation, prepared samples, data collection and interpretation. C.S. (University of Pretoria) was responsible for literature review writing and C.G.C. (Cavite State University) supervised the research project and the design.

\section{References}

Adeyemo, K.S. (2013). Management techniques for school administrators: Decisionmaking paradigm. Philippines: Rex Publications.

Altbach, P., Reisberg, L., \& Pacheco, I. (2012). Paying the professoriate: A global comparison of compensation and contracts. New York: Routledge.

Bell, M. (1995). The social construction of gender in the superintendency. Journal of Education Policy, 15(3), 93-316. http://dx.doi.org/10.1080/02680930050030446

Bexley, E., James, R., \& Arkoudis, S. (2011). The Australian academic profession in transition: Addressing the challenge of reconceptualising academic work and regenerating the academic workforce. Retrieved April 08, 2014, from http:// www.cshe.unimelb.edu.au/people/bexley_docs/The_Academic_Profession_in Transition_Sept2011.pdf

Brown, R. (2004). Design jobs that motivate and develop people. Retrieved August 22, 2013, from http://www.media-associates.co.nz/fjobdesign.html

Bundy, C. (2006). Global patterns, local options: Changes in higher education internationally and some implications for South Africa, in (CHE 2006). Kagisano, 4 (Winter), 1-20.

Cavite State University (CVSU) Module. (2008). Strategic human resources management (HREM 215). Unpublished CVSU PhD module.

Commission on Higher Education (CHED). (2009). Commission on higher education report. Retrieved February 15, 2011, from http://202.57.63.198/chedwww/index. php/eng/Information/CHED-Publications/Annual-Reports

Cunningham, J.B., \& Eberle, T. (1990). A guide to job enrichment and redesign. Retrieved August 20, 2013, from http://faculty.washington.edu/ janegf/jeguide. pdf

Davis, K. (1997). Human behaviour at work: Organizational behaviour. (5th edn.). New York: McGraw-Hill.

Deom Drez, J. (1999). Motivation through needs, job design, and satisfaction. Chapter 7, slide 20. Retrieved February 14, 2014, from http://www.sui.edu/departments/ cola/psyc323/chat07/index.htm

Department of Labour and Employment (DOLE). (2011-2013). Bureau of labour and employment statistics. Retrieved June 19, 2013, from http://www.bles.dole.gov. ph/PUBLICATIONS/Current $\% 20$ Labor\%20Statistics/STATISTICAL\%20TABLES/ eCLS_January.pdf

Govender, P., \& Parumasur, S. (2010). Evaluating the roles and competencies that are critical considerations for management development. SA Journal of Industrial Psychology, 36(1), 1-11. http://dx.doi.org/10.4102/sajip.v36i1.835

Grogan, M., \& Andrews, A. (2002). Defining preparation and professional development for the future. Educational Administration Quarterly, 38(2), 233-256. http:// dx.doi.org/10.1177/0013161X02038002008

ICFAI University. (2005). Managerial effectiveness: Managing the self and others. ICFAI Center for Management Research. Hyderabad: ICFAI University Press.

Jackson, B.L., \& Kelley, C. (2002). Exceptional and innovative programs in educational leadership. Educational Administration Quarterly, 38, 192-212. http://dx.doi. org/10.1177/0013161X02382005

Jennings, D.F., Hunt, T.G., \& Munn, J.R. (1996). Ethical decision-making: An extension to the group level. Journal of Managerial Issues, 8, 425-439. 
Knapp, M.S., Copland, M.A., \& Talbert, J.E. (2003). Leading for learning: Reflection tools for school and district leaders. Seattle, WA: Center for the Study of Teaching tools for schoc

Kotila, O. (2001). Job enrichment. Retrieved August 22, 2013, from http://academic. emporia.edu/smithwil/001fmg456/eja/kotila456.html

Leach, D., \& Wall, T. (2004). What is job design? Retrieved August 22, 2013, from http://www.shef.ac.uk/ iwp/publications/whatis/job_design.pdf

Locke, W., \& Teichler, U. (2007). The changing conditions of academic work and careers in select countries. Kassel: University of Kassel.

Lunenburg, F., \& Ornstein, A. (2008). Decision making. Educational administration Concepts and practices. (5th edn.). Thomson Brooks/Cole. (Electronic Version) Retrieved January 09, 2011, from https://books.google.co.za/books?id=RfkIAA AAQBAJ\&pg=PT343\&lpg=PT343\&dq=Lunenburg,+F.+and+\%26+Ornstein, + A. + 2008),\&source=bl\&ots=PRSc-dZ_mL\&sig=QZngXEIE76pdXie7nqhW6AvvUeE\& $\mathrm{I}=$ en\&sa=X\&ved=0CDgQ6AEwBWoVChMIgPC7wqGKxwIVhekUCh2yTwCZ\#v=on epage\&q=Lunenburg $\% 2$ C $\% 20 F . \% 20$ and $\% 20 \% 26 \% 20$ Ornstein $\% 2$ C $\% 20$ A. $\% 20$ (2008)\%2C\&f=false

MacDade, S.A. (2008). Higher education leadership development in the marketplace. In A.K. Kezar (Ed.), Rethinking leadership in a complex multicultural, and global environment: New concepts and model for higher education (pp. 213-230). Stylus Publishing, LLC.

Manjider, K.T., \& Priyan, K. (2009). Higher education: Reforms in teacher education. The International Journal of Research and Review, 3, 50.

Mione, P. (n.d.). Job enrichment. Retrieved August 22, 2013, from http://edweb.sdsu. edu/people/arossett/pie/Interventions/jobdesign_1.htm

Niehoff, B.P., Moorman, R.H., Blakely, G., \& Fuller, J. (2008). The influence of employment and job enrichment on employee loyalty in a downsizing environment. Organizational Research Method, 11, 148-159. http://dx.doi.org/10.1177/ 1059601101261006

Orpen, C. (2011). The effect of job enrichment on employee satisfaction, motivation involvement, and performance: A field experiment. Human Relations, 59, 783-814. http://dx.doi.org/10.1177/001872677903200301
Pillai, K.R., Masood, A., Amoodi, S.S., Husain, K., \& Koshy, R. (2012). Factors underlying job enrichment among expatriate employees: A regiona perspective Abhigyan: The Free Library Retrieved June 13, 2013, from http://www. thefreelibrary.com/Factors+underlying+job+enrichment+ among+expatriate+employees $\% 3 \mathrm{~A}+\mathrm{a} . .$. -a0315222381

Queen, T.L., \& Hess, T.M. (2010). Age differences in the effects of conscious and unconscious thought in decision-making. Psychology and Aging, 25(2), 251. PMID: 20545411, http://dx.doi.org/10.1037/a0018856

RAND Corporation Report. (1994-2011). Retrieved January 08, 2011, from http:// www.rand.org/pubs/monograph_reports/MR1679/MR1679.ch7.pdf

Riehl, B. (2000). Job enrichment: One avenue to retaining strong staff and providing quality service or they really can do more than interpret. Retrieved March 12, 2011, from http://www.pepnet.org/confpast/2000/pdf/riehl.pdf

Rhoades, G. (1998). Managed professionals: Unionized faculty and restructuring academic labour. New York: SUNY Press.

Rodeles, F.O. (2009). The environmental condition of the college of education SY 2006-2007: Input to PAASCU accreditation. The La Salle University-Dasmarinas Journal of Education, 2, 139-145.

Sarmiento III, U.P. (2008). The manual of regulation for private higher institution (Electronic Version). Retrieved April 16, 2010, from http://www.ched.gov.ph/wpcontent/uploads/2013/05/Manual-of-Regulations-for-Private-Higher-Education.pdf

Uduji, J.I. (2013). Job enrichment: A panacea to the problem of the demotivated marketing executive in the banking industry in Nigeria. European Journal of Business and Management, 5, 13.

Umstot, D.D., Bell, C.H., \& Mitchell, T.R. (1976). Effect of job enrichment and task goals on satisfaction and productivity: Implication for job design. Journal of Applied Psychology, 61(14), 379-394. http://dx.doi.org/10.1037/0021-9010.61.4.379

Valero, C.A. (1997). Application of qualitative and quantitative techniques of management in administrative/academic decision-making in Institution of Higher Education in Virginia. Unpublished doctoral thesis, Virginia Polytechnic Institute and State University. Retrieved November 12, 2010, from http://scholar.lib. vt.edu/theses/public/etd-65916251972550/etd.pdf 